\title{
Application of Rainfall-Potential Evapotranspiration Model for Determining Optimum Planting Date of Yam (Dioscorea rotundata) in a Tropical Wet-and-Dry Climate
}

\author{
A. O. Eruola ${ }^{1, *}$, N. J. Bello ${ }^{1}$, G. C. Ufoegbune ${ }^{1}$, A. A. Makinde ${ }^{2}$ \\ ${ }^{1}$ University of Agriculture, Abeokuta \\ ${ }^{2}$ National Horticultural Research Institute, Ibadan
}

\begin{abstract}
The application of Rainfall-Potential evapotranspiration (P-PE) model to yam (Dioscorea rotundata) Production was carried out in an on-farm yam trial during the 2006-2007 and 2007-2008 cropping seasons in Abeokuta, South western Nigeria. The experiment was a $3 \times 2$ factorial arrangement of three varieties of yam (Efuru, Ise-osi and Oniyere), two planting dates (early and late). The resulting 6 treatments were replicated three times with 14 mounds in each plot, in randomized complete block design. The general model for selecting the planting date of each yam cultivar in the two experimental years was $0.1 \mathrm{PE}<\mathrm{P}<0.5 \mathrm{PE}$. This was partitioned for the purpose of attaining optimal planting date into early and late, respectively as $\Sigma(\mathrm{P}-0.1 \mathrm{PE}) \leq 0$ designated as $\mathrm{T}_{1}$ and $\Sigma(\mathrm{P}-0.5 \mathrm{PE}) \leq 0$ as $\mathrm{T}_{2}$. For the rest of the season defined by $\mathrm{P}>\mathrm{PE}$, the physiological parameters and hydrothermal agro-climatic indices measured during the different phenological stages of yam grown were analyzed with respect to the various treatments. The result showed that model $\mathrm{T}_{1}$ defined as $\Sigma(\mathrm{P}-0.1 \mathrm{PE}) \leq 10 \mathrm{~mm}$ appeared as the best model that significantly $(\mathrm{P}<0.05)$ influenced emergence rate, phenological growth and tuber yield. The implications of the study for appropriate schedule of farm operations vis à-vis agronomic practices for yam cultivation have been noted.
\end{abstract}

Keywords Yam, Rainfall-Potential Evapotranspiration, Planting Date, Agro-Climatic Indices

\section{Introduction}

Yam is an important tuber crop in Nigeria and the entire West African region. Nigeria produces about $74 \%$ of the total world annual output of about 25million tones of yam[7]. However, climate change and variability particularly increasing anomaly in the onset, cessation and duration of the rains and incidence of dry spells during the early growth stages of yam has led to low production of yam in many yam growing areas in Nigeria. Consequently, for economic reasons, a number of farmers have shifted to other crops. This has led to relatively low supply and an increase in the price of yam tubers. There is no doubt that tuber yield is influenced by climatic condition, fertile soil, quantity of planting material (seed yam) and considerable labour input and effective agronomic operation[9]. But the variability of moisture based agro-meteorological indices appears as the most critical factor for yam production in the humid tropics. The major concern of farmers is how to minimize the damage to crops during the periods when rainfall exceeds potential

* Corresponding author:

layosky@yahoo.com (A.O. Eruola)

Published online at http://journal.sapub.org/plant

Copyright (C) 2012 Scientific \& Academic Publishing. All Rights Reserved evapotranspiration as well as the effect of deficiencies arising from incidence of dry spells when potential evapotranspiration exceeds rainfall amount during the preparatory period. It follows therefore that the P- PE model assumes a great significance in assessing water supply for agriculture and particularly for schedule of farm operations of a crop particularly yam in a rain-fed agricultural region. To this end, this study intends to apply P-PE model to the determination of optimum planting date of white yam in tropical wet-and-dry climate.

\section{Materials and Methods}

\subsection{Description of the Study Area}

The field experiment was conducted at the Teaching and Research farm of University of Agriculture along Alabata road, Abeokuta $\left(7^{\circ} 15^{\prime} \mathrm{N}, 3^{\circ} 25^{\prime} \mathrm{E}\right)$ in Odeda Local Government Area of Ogun State, South Western Nigeria during the 2007 and 2008 cropping seasons(Fig. 1). The study area is characterized by a tropical climate with distinct wet and dry seasons with bimodal rainfall pattern and mean annual air temperature of about $30^{\circ} \mathrm{C}$. The actual rainfall totals during the 2007 and 2008 cropping season were 1177.2 and $1201.6 \mathrm{~mm}$, respectively. The region is characterized by 
relatively high temperature with mean annual air temperature being about $30^{\circ} \mathrm{C}$. The soil at the experimental site was categorized as a well-drained tropical ferruginous soil. The A horizon of the soil is an Oxic Paleudulf of the Iwo series with $83 \%$ sand, $5 \%$ silt and $12 \%$ clay with a pH of 6 considered tolerable for yam cultivation[8].

\subsection{Experimental Design and Field Measurement}

The experimental land $30 \times 60 \mathrm{~m}^{2}$ had been previously cultivated with beans and groundnut intercrop but left to fallow for over 3 years (from 2004-2006). The site was cleared manually in November 2006, in preparation for the 2006-2007 cropping following the popular practice by the farmers in the study area. This period marks the preparatory period for the cultivation of early yam planting in the study area. Yam mounds were made manually using African hoe during the two experimental years. The mounds were of height $60 \mathrm{~cm}$ and spaced $1.5 \times 1.5 \mathrm{~m}^{2}$ a walk way of $1 \mathrm{~m}$ between adjacent row. The mound tillage system was selected for the study not only because it is the most widely use method in the study area, but also because it improves the soil aeration and hydrothermal conditions for crops emergence, root development, crop growth and yield[5]. Three local white yam, Dioscorea rotundata cultivars (Efuru, ' $\mathrm{A}_{1}$; Ise-osi ' $\mathrm{A}_{2}$; and Oniyere ' $\mathrm{A}_{3}$ ) were used. The choice of selection was due to the fact that the cultivars were the most important edible yams widely grown by farmers in the University's extension villages around the study area. During each year of study, rainfall-potential evapotranspiration (P-PE) model according to the procedure of[2] were followed to determine start and end of planting. The model used in this study was formulated to incorporate farmer's conventional calendar for yam cultivation. Consequently, planting date was selected based on the following general model

$$
0.1 \mathrm{PE}<\mathrm{P}<0.5 \mathrm{PE}
$$

where

$\mathrm{PE}=$ Potential evapotranspiration

$\mathrm{P}=$ Rainfall

$0.1 \mathrm{PE}=$ Onetenth the potential evapotranspiration

$0.5 \mathrm{PE}=$ Half the potential evapotranspiration

Two specific planting dates $\left(T_{1} \& T_{2}\right)$ generated from the general model above is as below

Where

$$
\begin{aligned}
& \mathrm{T}_{1}=\Sigma(\mathrm{P}-0.1 \mathrm{PE}) \leq 0 \\
& \mathrm{~T}_{2}=\Sigma(\mathrm{P}-0.5 \mathrm{PE}) \leq 0
\end{aligned}
$$

$\Sigma(\mathrm{P}-0.1 \mathrm{PE}) \leq 0=$ accumulated difference between rainfall (P) and one tenth the potential evapotranspiration (PE) is zero

$\Sigma(\mathrm{P}-0.5 \mathrm{PE}) \leq 0=$ accumulated difference between $\mathrm{P}$ and half $P E$ records zero

The terms $\mathrm{P}, \mathrm{PE}, 0.1 \mathrm{PE}$ and $0.5 \mathrm{PE}$ are as previously defined.

It follows that the two planting dates $\left(\mathrm{T}_{1} \& \mathrm{~T}_{2}\right)$ in each experimental years were determined from the model. For instance, the planting dates for the 2006-2007 experimental year are as below

$\mathrm{T}_{1}=\Sigma(\mathrm{P}-0.1 \mathrm{PE}) \leq 24 \mathrm{~mm}=$ March 22 which fell in the $9^{\text {th }}$ decade of 2007

$\mathrm{T}_{2}=\Sigma(\mathrm{P}-0.5 \mathrm{PE}) \leq 259 \mathrm{~mm}=$ June 5 which fell in the $16^{\text {th }}$ decade of 2007

Whereas the planting dates for the 2007-2008 experimental year happened to be:

$\mathrm{T}_{1}=\Sigma(\mathrm{P}-0.1 \mathrm{PE}) \leq 10 \mathrm{~mm}=$ January 21 which fell in the $3^{\text {rd }}$ decade of 2008

$\mathrm{T}_{2}=\Sigma(\mathrm{P}-0.5 \mathrm{PE}) \leq 182 \mathrm{~mm}=$ April 6, 2008 which fell in the $10^{\text {th }}$ decade of 2008

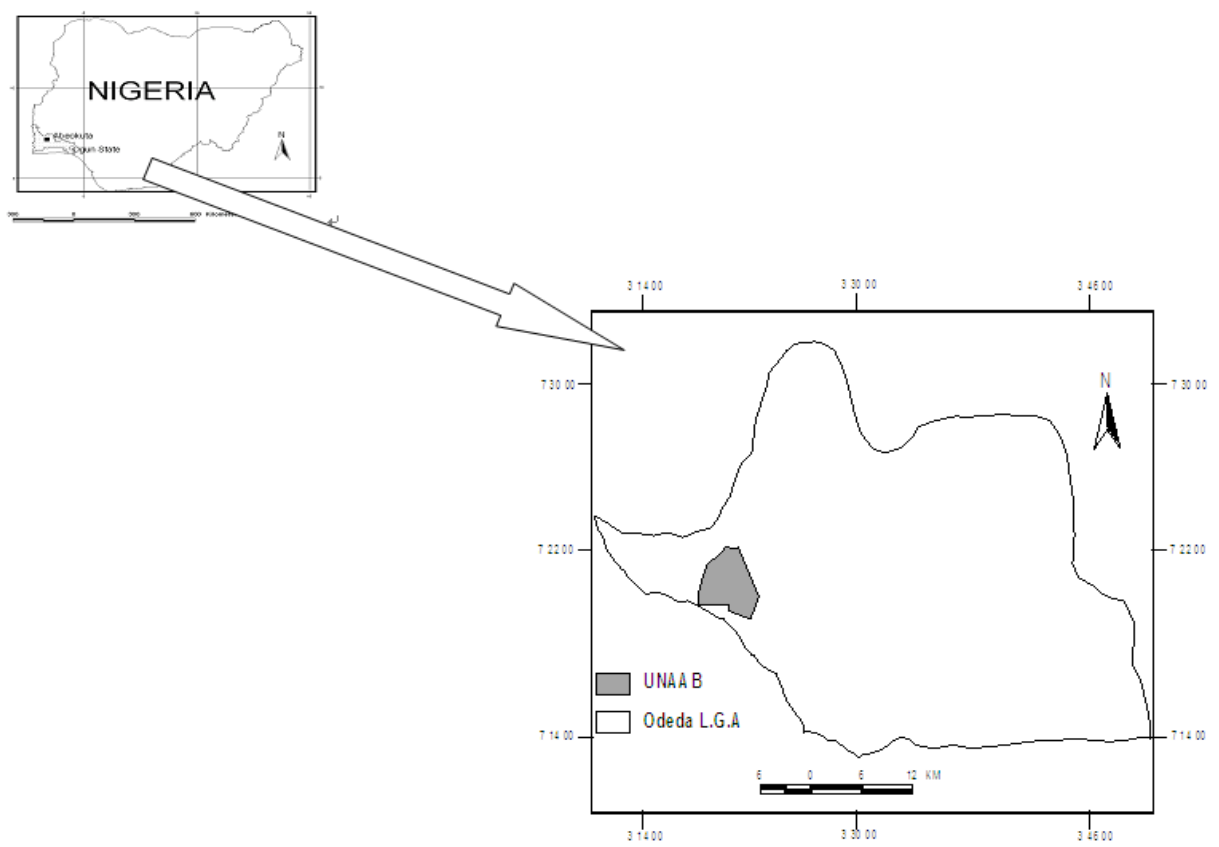

Figure 1. Location of University of Agriculture, Abeokuta within Odeda Local Government Area in Ogun State, Southwestern Nigeria. 
Figures $2 \& 3$ showed the planting dates for the two cropping seasons 2007 and 2008 respectively.

Using a new knife, each yam cultivar was cut into yam setts weighing an average of 550grams, and planted at an average depth of $15 \mathrm{~cm}$ on mounds. The experimental plots were laid out in randomized complete block design (RCBD) with three replicates. After sprouting, the yams were staked to about $3 \mathrm{~m}$ high and the vines were trained regularly. No fertilizer and insecticide were applied and all plots were regularly hand weeded. Bush rat was controlled by regular clearing of the surroundings of the project site.

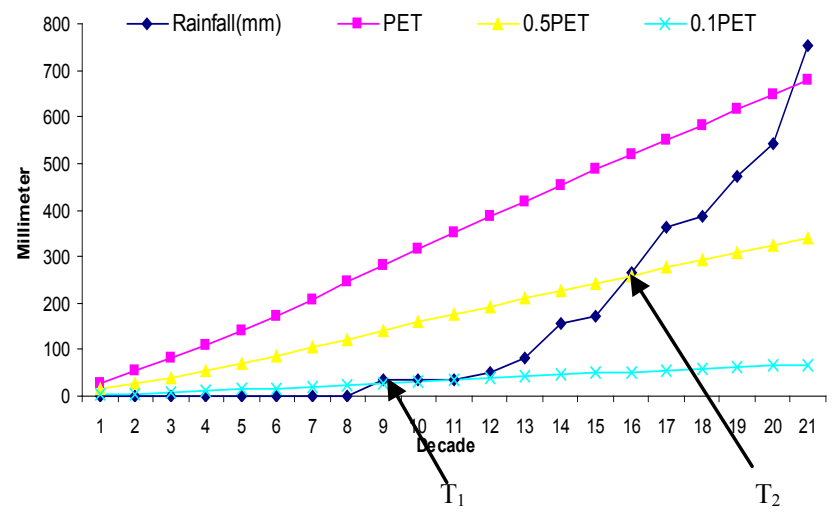

Where PET $=$ Potential Evapotranspiration $\mathrm{T}_{1}=$ date of $1^{\text {st }}$ planting according to P-PE model $\mathrm{T}_{2}=$ date of $2^{\text {nd }}$ planting according to P-PE model

Figure 2. Planting dates as determined using decadal cumulative rainfall-potential evapotranspiration (P-PE) model in 2007 cropping season.

The result of yield from experiment (as determined from rainfall - PE model) and the yield obtained from farmers in University's extension villages around the study area, the data gathered from Ogun State Ministry of Agriculture and Ogun state Agricultural Development Program were compared to ascertain the effectiveness of model. The yield from farmers in University's extension villages around the study area were determined from questionnaire administered during the two experimental years.

\section{Results and Discussion}

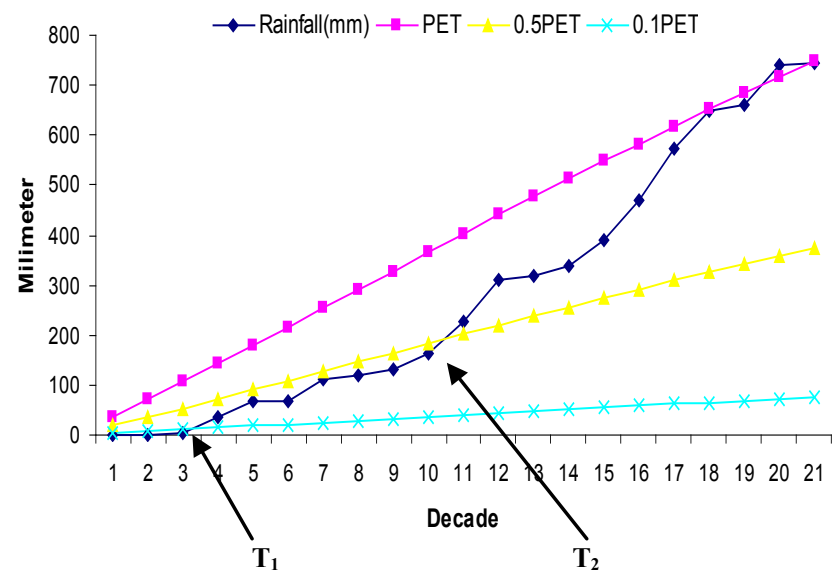

Figure 3. Planting dates as determined using decadal cumulative rainfall potential evapotranspiration (P-PE) model in 2008 cropping season.

In the present study, the P-PE model date of early planting designated $T_{1}$, coincided with the date during which the accumulated differences between rainfall $(\mathrm{P})$ and one tenth of the potential evapotranspiration (PE) is zero [i.e $\Sigma(\mathrm{P}-0.1 \mathrm{PE}) \leq 0] . \mathrm{T}_{1}$ had significant influence on emergence rate, vine length, number of leaves, number of branches, number of roots, root length, LAI, tuber length, tuber diameter, tuber weight, number of tuber yield for $2007 \mathrm{ex}$ perimental year (Table 1\&2).

Rainfall variability in 2007 was characterized by late onset of rainfall (i.e. the accumulated difference between $\mathrm{P}$ and $0.5 \mathrm{PE}$ was very high as shown in Figure 2 . There was prolonged dry spell after planting, during sprouting, emergence period but unbroken succession of wet days at the critical water requirement stage of bulking. These parameters were higher in early planting than late planting. However, the delay in planting using the model date in 2007 experimental year gave a better yield than when the farmer's calendar date (OGADEP) was used as shown in Figures. 4 \& 5.

Table 1. Effect of planting date on growth of three white yams grown at Abeokuta during 2007 cropping season.

\begin{tabular}{|c|c|c|c|c|c|c|c|c|c|}
\hline Factor & Emer.\% & $\begin{array}{l}\text { Vine length } \\
(\mathrm{cm})\end{array}$ & No. branch & No. leaves & No. roots & $\begin{array}{l}\text { Vine } \varnothing \\
(\mathrm{cm})\end{array}$ & $\begin{array}{l}\text { Branch length } \\
(\mathrm{cm})\end{array}$ & $\begin{array}{l}\text { Root length } \\
(\mathrm{cm})\end{array}$ & LAI \\
\hline \multicolumn{10}{|c|}{ Planting season } \\
\hline $\mathrm{T}_{1}$ & $54.6 \pm 5.57$ & $137.6 \pm 22.9$ & $21.8 \pm 2.04$ & $776.3 \pm 98.74$ & $24.3 \pm 2.33$ & $1.424 \pm 0.06$ & $68.7 \pm 5.66$ & $32.8 \pm 2.58$ & $1.396 \pm 0.32$ \\
\hline $\mathrm{T}_{2}$ & $31.7 \pm 4.83$ & $15.3 \pm 4.38$ & $15.2 \pm 1.92$ & $191.6 \pm 29.76$ & $16.2 \pm 1.67$ & $1.352 \pm 0.05$ & $59.6 \pm 5.60$ & $24.5 \pm 1.94$ & $0.141 \pm 0.04$ \\
\hline $\mathrm{P}$ & $<0.001 *$ & $<0.001^{*}$ & $0.017 * *$ & $<0.001^{*}$ & $0.009 *$ & 0.266 & 0.217 & $0.016^{* *}$ & $<0.001^{*}$ \\
\hline
\end{tabular}

*Significant at $\mathrm{P}<0.01 * *$ Significant at $\mathrm{P}<0.05$

Table 2. Effect of planting date on yield and yield characteristic of white yams grown at Abeokuta during 2007 cropping season.

\begin{tabular}{|c|c|c|c|c|c|}
\hline Factor & Tuber length $(\mathrm{cm})$ & Tuber diameter $(\mathrm{cm})$ & Tuber weight $(\mathrm{kg})$ & No of tuber & Harvest yield ton/ha \\
\hline \multicolumn{6}{|c|}{ Planting Date } \\
\hline $\mathrm{T}_{1}$ & $30.0 \pm 2.73$ & $8.30 \pm 0.73$ & $2.60 \pm 0.25$ & $1.019 \pm 0.13$ & $8.04 \pm 1.17$ \\
\hline $\mathrm{T}_{2}$ & $9.4 \pm 2.48$ & $2.59 \pm 0.67$ & $0.58 \pm 0.16$ & $0.370 \pm 0.95$ & $1.42 \pm 0.41$ \\
\hline $\mathrm{P}$ & $<0.001 *$ & $<0.001 *$ & $<0.001 *$ & $<0.001^{*}$ & $<0.001 *$ \\
\hline
\end{tabular}

*Significant at $\mathrm{P}<0.01 \quad * *$ Significant at $\mathrm{P}<0.05$ 
Table 3. Effect of planting date on growth of three white yams grown at Abeokuta during 2008 cropping season.

\begin{tabular}{|c|c|c|c|c|c|c|c|c|c|}
\hline Factor & $\begin{array}{c}\text { Emer } \\
\%\end{array}$ & $\begin{array}{c}\text { Vine length } \\
(\mathrm{cm})\end{array}$ & $\begin{array}{c}\text { No. } \\
\text { branch }\end{array}$ & No. leaves & No. roots & $\begin{array}{c}\text { Vine } \varnothing \\
(\mathrm{cm})\end{array}$ & $\begin{array}{c}\text { Branch length } \\
(\mathrm{cm})\end{array}$ & $\begin{array}{c}\text { Root length } \\
(\mathrm{cm})\end{array}$ & LAI \\
\hline \multicolumn{1}{|c|}{ Planting Date } \\
\hline $\mathrm{T}_{1}$ & $74.0 \pm 4.13$ & $381 \pm 40.29$ & $25.1 \pm 2.97$ & $568.1 \pm 57.22$ & $29.4 \pm 2.82$ & $1.465 \pm 0.05$ & $94 \pm 9.13$ & $35.5 \pm 2.60$ & $1.230 \pm 0.17$ \\
$\mathrm{~T}_{2}$ & $68.5 \pm 4.6$ & $357 \pm 28.03$ & $19.4 \pm 2.58$ & $332.6 \pm 28.65$ & $21.5 \pm 2.19$ & $1.348 \pm 0.06$ & $62.7 \pm 5.92$ & $28.2 \pm 2.02$ & $0.628 \pm 0.10$ \\
$\mathrm{P}$ & 0.205 & 0.424 & 0.121 & $<0.001^{*}$ & $0.05^{* *}$ & 0.109 & $0.008^{*}$ & $0.044^{* *}$ & $<0.001^{*}$ \\
\hline
\end{tabular}

*Significant at $\mathrm{P}<0.01 * *$ Significant at $\mathrm{P}<0.05$

Table 4. Effect of planting date on yield and yield characteristic of three white yams grown at Abeokuta during the 2008 cropping season.

\begin{tabular}{|c|c|c|c|c|c|}
\hline Factor & Tuber length $(\mathrm{cm})$ & Tuber diameter $(\mathrm{cm})$ & Tuber weight $(\mathrm{kg})$ & No of tuber & Harvest yield ton/ha \\
\hline \multicolumn{6}{|c|}{ Planting Date } \\
\hline $\mathrm{T}_{1}$ & $37.7 \pm 2.13$ & $11.49 \pm 0.644$ & $3.55 \pm 0.24$ & $1.133 \pm 0.06$ & $12.70 \pm 1.16$ \\
$\mathrm{~T}_{2}$ & $34.7 \pm 1.56$ & $11.14 \pm 0.43$ & $3.13 \pm 0.18$ & $1.115 \pm 0.03$ & $10.71 \pm 1.14$ \\
$\mathrm{P}$ & 0.223 & 0.575 & 0.098 & 0.764 & $0.043^{* *}$ \\
\hline
\end{tabular}

*Significant at $\mathrm{P}<0.01 * *$ Significant at $\mathrm{P}<0.05$

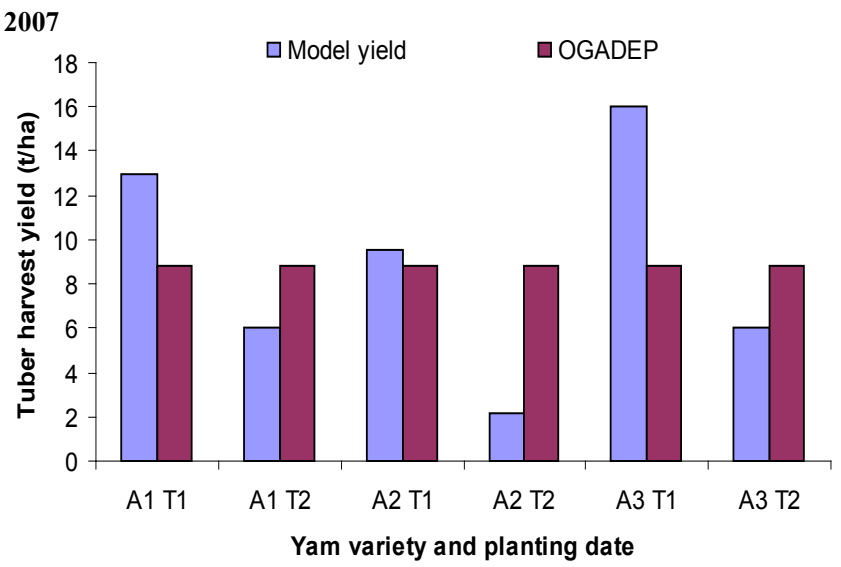

Where $\mathrm{T} 1=$ date of $1^{\text {st }}$ planting according to P-PE model $\mathrm{T}_{2}=$ date of $2^{\text {nd }}$ planting according to P-PE model A1,A2,\&A3 = Efuru, Ise osi \& Oniyere ( white yam varities)

Figure 4. Effect of planting date on tuber yield of three white yams grown at Abeokuta in 2007 cropping season.

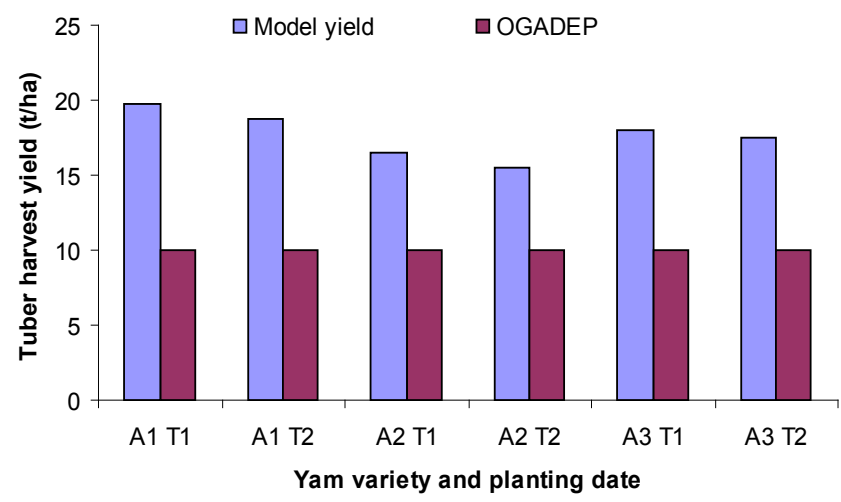

Figure 5. Effect of planting date on tuber yield of three white yams grown at Abeokuta in 2008 cropping season.

In 2008 experimental year, early planting was characterized by low accumulated difference between $\mathrm{P}$ and $0.5 \mathrm{PE}$ which gave no significant difference at $\mathrm{P}>0.05$ between early planting $T_{1}$ and late planting $T_{2}$ on the emergence rate, vine length, number of branches, number of roots, vine diameter, root length, branch length, tuber length, tuber diameter, tuber weight, number of tuber and harvest yield
(Table 3 \& 4). However, for the 2008 experimental year, the P-PE model date of early planting $\mathrm{T}_{1}$ had significantly influenced number of leaves and LAI. The high leaf area during the early season can be attributed to adequate moisture availability while the high LAI was due to high leaves production and retention of leaves during the early planting than the late planting. The amount of leaf area available during tuber bulking period largely determines tuber yield in yam $[3,4]$.

Generally, the early planting particularly when the value of accumulated difference between $\mathrm{P}$ and $0.5 \mathrm{PE}$ were low as in 2008 cropping season was observed to have more yield when compared to early planting of 2007 cropping season that had high accumulated difference between $\mathrm{P}$ and 0.5PE which agreed with[1]. Furthermore, the early planting $T_{1}$ when $\Sigma(\mathrm{P}-0.1 \mathrm{PE}) \leq 0$ was observed to have more yield than late planting $\mathrm{T}_{2}$ when $\Sigma(\mathrm{P}-0.5 \mathrm{PE}) \geq 0$ in both experimental years. The high yield from the early planting than the late planting for both experimental years related to the higher LAI which ensures higher bulking rate for a longer period[10] and can also be attributed to phosphorus and mineralized nitrogen which are naturally high during the early rains absorbed by yams during growth[6,10]. While the significant low yield arising from delayed planting until the 9th decade of 2007 experimental year using model and even lower yield when farmer's conventional method (calendar year) was used implied that these natural nutrients were largely unavailable as they might have been lost to leaching. This is more so in view of the fact that the accumulated difference between $\mathrm{P}$ and $0.1 \mathrm{PE}$ at the $9^{\text {th }}$ decade of 2007 had become significantly high (14-28mm). It is noteworthy that in the case of late onset of rains, farmers may become apprehensive of a planting date that fails to ensure that the crop matures by the end of the rains. Consequently, they may tend to plant immediately after the value of accumulated difference between $\mathrm{P}$ and $0.5 \mathrm{PE}$ approaches zero in other to avoid possible incidence of drought at critical moisture period of bulking. In the same vein, significant declined in yield occurred when accumulated difference between $\mathrm{P}$ and $0.1 \mathrm{PE}$ was in excess of $10 \mathrm{~mm}$. Thus planting can be done when accumulated 
difference between $\mathrm{P}$ and $0.1 \mathrm{PE}$ is less than $10 \mathrm{~mm}$ (i.e $\Sigma(\mathrm{P}-0.1 \mathrm{PE}) \leq 10 \mathrm{~mm})$. The implication for the schedule of farm operations for yam cultivation in the area is that land preparation could commence as soon as the accumulated difference between $\mathrm{P}$ and 0.1PE approaches zero while mound construction and planting could be done simultaneously immediately. Under no circumstance must farmer delay planting until the accumulated difference exceed $10 \mathrm{~mm}$. This schedule is to ensure that adverse effects of high actual water availability are avoided or minimized while, at the same time, precautions are taken against possible shortfall in the duration of the rains, particularly if such an early

onset of the rains is flawed by an abnormal early or sudden cession. In a situation where the onset of the rains is extremely late such that incidence of drought is imminent and the duration of the rains might possibly fall short of 240days (24dacades- growing days of yam), then variety with phenology that synchronize perfectly with the pattern of actual water availability should be selected. Furthermore, apart from the application of mulch immediately after planting to check evaporation and drying out of the plant-soil environment, since leaching of the soil nutrients tends to increase with higher accumulated difference between $\mathrm{P}$ and $0.1 \mathrm{PE}$ particularly when it is tending towards $\Sigma(\mathrm{P}-0.5 \mathrm{PE})=$ 0 , it implies that for good yield, the use of fertilizer (particularly nitrogen and phosphorous) might be necessary if there is incidence of abnormal heavy and regular downpours immediately after planting. Usually in view of the highly variable nature of rainfall in the climatic region, initial top dressing with $50 \mathrm{~kg} / \mathrm{ha} \mathrm{N}+60 \mathrm{~kg} / \mathrm{ha} \mathrm{K}_{2} \mathrm{O}$ [10] fertilizer is quite appropriate.

\section{REFERENCES}

[1] N.J. Bello. Application of rainfall- potential evapotranspiration model for the determination of optimum planting date of maize (Zea mays) in a tropical wet and dry climate. Indian Journal of Agricultural Sciences. 70 (7):437-440. 2000

[2] J. Cocheme and P. Franquin. An agroclimatological survey of a semi arid area in Sourth of the Sahara. WMO Technical note No. 86, Geneva.1967

[3] L. Degras. The yam: A Tropical crop. London and Basingstoke, Macmillan. 53-85pp. 1993

[4] B.A.A. Enyi. The effects of seed size and spacing on growth and yield of lesser yam (Dioscorea esculenta). Journal of Agricultural Science (Cambridge) 78: 215. 1972

[5] A.D. Kutugi. Comparative analysis between indigenous and modern tiilage practices in the production of Dioscorea rotundata and Dioscorea cayenensis in the middle belt of Nigeria. Journal of Agriculture and Environment 2(1): 53-66. 2002

[6] C.A. Okoh. The effect of mulching on soil physico-chemical properties and the yield of White Yam. Trop. J. Root Tuber Crops 4(2): 24-31. 2004

[7] F.O. Olasantan. Effect of mulching on soil temperature and moisture regime and emergence, growth and yield of white yam in western Nigeria. Soil and tillage research 50: 215-221. 1999

[8] F.O. Olasantan. Effect of population density and sowing date of pumpkin on soil hydrothermal regime, weed control and crop growth in a yam -pumpkin intercrop. Experimental Agriculture 43: 365-380. 2007

[9] G.C. Orkwor. Studies on the critical period of weed interference in yam intercropped with maize (Zea mays L.), Okra (Abelinoschus esculentus L. Moench), Sweet potato and the biology of associated weeds. Ph.D thesis. University of Nigeria, Nsukka, Nigeria. 262pp. 1990

[10] R.A.Solubo. Studies on white yam (Doiscorea rotundata). II. Change in nutrient with age. Expl. Agriculture 8: 107-115. 1972 